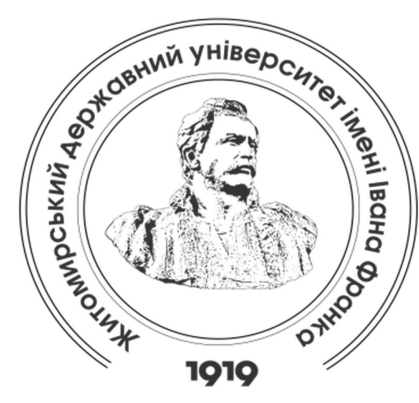

Zhytomyr Ivan Franko State University Journal. Pedagogical Sciences. Vol. 3 (106)

Вісник Житомирського державного університету імені Івана Франка. Педагогічні науки. Вип. 3 (106)

ISSN (Print): 2663-6387

ISSN (Online): 2664-0155

\author{
UDC 37.01/.09.111. $057+378.304(045)$ \\ DOI 10.35433/pedagogy.3(106).2021.53-61
}

\title{
ARRANGEMENT OF FUTURE INTERNATIONAL RELATIONS EXPERTS' INDIVIDUL WORK RELATED TO STUDYING ENGLISH DURING PRACTICAL CLASSES
}

\section{N. M. Vasylyshyna*}

At the present stage, individual work of international relations applicants for higher education, approaches to which require radical changes, should become the basis of higher education, an important part of the training process of future experts. Moreover, individual work is considered to be a holistic integral formation that consists of various types of individual and collective activities for applicants for higher education, which are carried out by them in the classroom. In the frame of our research, the purpose of individual work of international relation applicants for higher education is twofold: independence development as a personality trait and English knowledge acquisition along with skills formation. We have verified that it contributes to the development of initiative, creativity, discipline, independence, accuracy, sense of responsibility, ability to solve problems on their own, ability to find constructive solutions, get out of crisis situations that are so necessary for the future specialists in their training and professional activities. In the frame of organizing the research, we optimally combined a set of methods, taking care that such a combination provides a comprehensive information about the development of foreign language communicative competence of future specialists. The methods that were used had to ensure the simultaneous study of activities, communication and awareness of the applicants for higher education. In the ongoing pedagogical research the theoretical research methods were applied. During the pedagogical investigation we have come up to the idea that there are some sufficient modern teaching methods active introduction of which will increase the educational outcomes of the foreign language competence of modern applicants for higher education. So, we have witnessed that the usage of think-outside-the-box activities, such as: gapped texts, pairs of sentences, mini-dialogues, sentence transformations, word-building and sentence formation are likely to provide a set of soft skills necessary for modern applicants for higher education of international relations specialty. We have conducted the research related to possible application of modern teaching techniques, such as: collaborative learning, cooperation of the peers, task-based or activity-based, as well as self-learning. Besides, all these modern methods were supplemented with specially designed real-life activities in English suitable for different foreign language classes. We have created a logical step by step strategy of modern method application in the educational process of shaping foreign language communicative

\footnotetext{
* Doctor of Pedagogical Sciences, Associate Professor

(National Aviation University, Kyiv)

filologyN@gmail.com

ORCID: 0000-0002-0003-9998
} 
competence necessary for future experts. We believe that modern methodic gives a vast scenario which encourages learners of international relations specialty to study profoundly and study to satisfy their curiosity.

Key words: applicants for higher education, individual work, modern teaching methods, educational institutions, think outside the box activities, critical thinking skills, practical classes.

\section{ОРГАНІЗАЦІЯ САМОСТІЙНОЇ РОБОТИ МАЙБУТНІХ ФАХІВЦІВ 3 МІЖНАРОДНИХ ВІДНОСИН У ПРОЦЕСІ ВИВЧЕННЯ АНГАІЙСЬКОЇ МОВИ НА ПРАКТИЧНИХ ЗАНЯТТЯХ}

\section{H. М. Васимишина}

Самостійна робота студентів фракультету міжнародних відносин, підходи до якої потребують докорінних змін, на сучасному етапі має стати основою вищої освіти, важливою частиною проиесу фрахової підготовки майбутніх фахівиів. У межах дослідження ми розглядали самостійну роботу як иілісне інтегральне утворення, шо складається 3 різноманітних видів індивідуальної $і$ колективної діяльності студентів, які здійснюються ними на навчальних заняттях. Нами було визначено, ио мета самостійної роботи студентів факультету міжнародних відносин двоєдина: розвиток самостійності як риси особистості, шо логічно поєднується із засвоєнням англомовних знань, фрормуванням відповідних умінь та навичок. Крім того, ми довели, що самостійна робота у прочесі оволодіння англійською мовою сприяе виробленню у студентів ініціативності, креативності, дисииплінованості, самостійності, точності, почуття відповідальності, уміння самостійно вирішувати проблеми, знаходити конструктивні рішення, вихід з кризових ситуаиій, шо так необхідні майбутньому спеиіалістові в його навчанні і професійній діяльності. В рамках організаиії дослідження ми оптимально поєднали набір методів, дбаючи про те, шоб така комбінація надавала вичерпну інформацію про розвиток іншомовної комунікативноі компетентності майбутніх фахівиів. Використовувані методи повинні були забезпечити одночасне поєднання проиесу засвоєння знань та безпосереднє їх використання студентами у практичному спілкуванні. Різноманітність методів, які були застосовані у иьому педагогічному дослідженні, можна ідентифікувати як теоретичні методи дослідження. Під час педагогічного пошуку ми прийшли до висновків про наявність вагомих сучасних методів навчання, активне впровадження яких підвищить освітні результати іншомовноі компетентності сучасних студентів. Отже, ми стали свідками того, ио використання заходів "нестандартного мислення", таких як: прогалини в текстах, пари речень, мінідіалоги, перетворення речень, словотворення та формування речень, ймовірно, забезпечить розвиток "soft skills", необхідних для сучасних студентів спеціальності "Міжнародні відносини". Вперше ми провели дослідження сучасних технік навчання, таких як: спільне навчання, співпраия з однолітками, інтегративного та інтерактивного характеру, самонавчання, орієнтованого на реалізаиію завдань даного дослідження. Крім того, всі иі сучасні техніки супроводжувалися спеціально розробленими прикладами завдань призначеними для різних видів занять з англійської мови. Ми покроково створили логічну стратегію застосування сучасних методів у навчальному проиесі фрормування іншомовноі комунікативної компетентності, необхідної майбутнім фахівиям. Ми вважаємо, ило сучасна методика створюе підгрунття, яке заохочуе студентів старанно навчатися та може задовольнити їхню допитливість.

Ключові слова: здобувачі вищої освіти, самостійна робота, сучасні методи навчання, навчальні заклади, завдання для нестандартного мислення, навички критичного мислення, практичні заняття.

Introduction of the issue. The highest degree of development of the future specialist's personality is professionalism, which begins where an independent creative search of principles, methods, ways of behavior and activities of future experts are being carried out. After all, to achieve goals set 
by modern society, various professional fields demand a specialist who: is able to act independently, makes extraordinary decisions, is reasoned and can confidently defend his position, is able to think and work creatively, is responsible for the results of his activities. As a result, independence becomes a professional need for quality training of future specialists, that should not only be focused on the implementation of reproductive executive activity, which involves mastering a certain amount of knowledge, but also on the development of independence as a relative feature of the applicants for higher education, associated with his activity and the processes of self-realization of the individual $[3 ; 6]$.

The Law of Ukraine "On Education", namely the National Doctrine of Education Development in the XXI century sets the following task for higher educational institutions: to provide training of qualified personnel capable of creative work, professional development, implementation of scientific and information educational technologies that are competitive in the labor market $[3 ; 5 ; 6]$.

Current state of the issue. Over the years, there have been visible changes in teaching style. Opposite to the memorization and old recitation practice to teach the applicants for higher education, now with modern teaching methods, interactive methods of teaching have been introduced, and their result can be seen. This is an education reform which provides an entirely different angle of teaching and learning because modern teaching methods do not attribute to all applicants for higher education at the same level of their understanding ability, unlike the conventional methods of teaching. Rather than teacher based, modern teaching methods focus more on questioning, demonstration, explaining, practical, collaboration methods, and are more activity-based [1;4].

In recent years, the scope of knowledge in the field of science and technology has dramatically increased, and human's ability to adapt to new knowledge in science and technology has also boosted. So, there is an immense need for innovative and creative minds to explore unknown and unrevealed areas of different fields. To cope up with the modern world and the knowledge-driven era of technology, adopting modern ways are the only means to survive.

So, the applicants for higher education should be taught in a manner to tackle the 21-st century, which is technology-driven era and therefore requires creative and innovative minds for the progress of individuals, society, and nation. The applicants for higher education should get to know the modern teaching methods and are provided sufficient knowledge so that they can create opportunities for themselves and others [6].

\section{Outline of unresolved issues} brought up in the article. In the educational activity of higher education institutions of Ukraine during the previous ten years, in training of the applicants for higher education, the attention was focused on mastering of a significant amount of knowledge acquired on an extensive basis of the educational process organization. Under such conditions, it was quite difficult to ensure the appropriate level of intellectual development of the person, to prepare her for independent cognitive activity throughout life. Moreover, today's opportunities for organizing extensive educational activities of higher educational institutions have exhausted themselves [5; 7].

The importance of the development of students' individual work at different ages was reflected in the scientific works of pedagogy and psychology classics: J. Rousseau, J. Pestalozzi, F. Disterweg and others. Various aspects of students' independent work are analyzed in studies of many scientists and methodologists: A. Aleksyuk, V. Burak, V. Kozakov, O. Moroz, P. Podkasisty, 
O. Bilyaev, K. Plisko, M. Pentilyuk and others $[4 ; 6]$.

Also, in the studies of V. Zhukovsky, O. Moroz, K. Plisko it is argued that the main meaning of students' individual work is to learn to understand the essence of the subject problems, to establish relations and connections of concepts of different sciences, to analyze various components of a particular field of knowledge and, as a consequence, do generalizations and conclusions. Parallel can be done in teaching English [8].

The issue of individual work while learning a foreign language was broadly discussed in the works of $\mathrm{N}$. Zhuravskaya, S. Zaskaleta, L. Onuchak, H. Cooper, L. Painter and others. Therefore, we consider the research of the main components of the organization of independent work of applicants for higher education in the process of learning a foreign language to be expedient and relevant [4; 6;9].

Teachers still use a conventional chalk-talk method in the classroom to teach applicants for higher education who can provide only basic knowledge of foreign language. Their approach can no longer be used as this is outdated, with limited scope, and has been failed both at the national and personal levels [5; 8].

If teachers apply modern teaching methods instead of traditional impractical ones and present English language lessons in a more proper scientific way, then many problems, including unemployment, can be overcome. All this can be achieved by providing a strong pillar to the foreign language education system.

So, it requires an instant review of the curriculum of the discipline "Foreign Language", and it is the reason why modern teaching methods are introduced $[6 ; 7]$.

Modern teaching unquestionably is the need of the hour because of its relevance in the modern era. The revolution in the field of science and technology demands great ideas and extensive effort to deal with any kind of circumstances coming in the way of development. All the load is on the little shoulders of learners. So, it is vital to give applicants for higher education not only knowledge but to improve their skills from the very beginning [6].

Aim of the research. Considering the urgency and topicality of self-education application in modern English teaching process, we can identify the main purposes of the research, namely: the first part of the paper is dedicated to identifying important characteristics of modern teaching methods, in particular seven of them have been chosen; the second part of the paper is grounded on the provision of five useful "think outside the box activities" that can be used in the scope of mentioned above modern teaching methods.

Results and discussion. The modern teaching methods help to build or develop a productive understanding of English language practical classes. Hence, the elements of contemporary teaching methods include:

1. Learner-centered approach. One of the essential characteristics of the modern teaching methods in English language lessons is it is learner-centered. It focuses on learners while using or applying during classroom. The teacher acts only as a guide, and all the learning process involves learners. Learners appear as dominators in classroom interactions [2;7].

2. Task-Based or Activity-based approach. A teacher of English language practical classes organizes activity or task and engages applicants for higher education to learn this way. Hence it is the activity-based or commission-based approach. Applicants for higher education are offered or asked to take part in classroom interaction performing all these interactive activities [3; 7].

3. Self-learning approach. Curiosity always pushes the learner to discover new aspects of subject and master more knowledge at the same time. It drives him/her to learn and memorize large abstracts of the text that they will either 
miss gratefully or forget immediately. Through their curiosity, applicants for higher education get motivated to explore English as a foreign language. Teaching applicants for higher education to operate the internet and find results themselves helps them to be selfdependent and gives them a deep understanding of the English topic content. A teacher should allow the applicants for higher education to bring new ideas and work on them for the development of their brain and ability to work alone. This modern teaching method plays a significant role in learners' period of foreign language education [5; 7].

4. Interactive Approach. One characteristic defines the modern teaching method as very interactive. The teacher asks the applicants for higher education to form small groups or work as individuals to perform the English learning tasks and come up with the desired results. It helps them to gather knowledge from one another. Applicants for higher education learn to work together and a sense of cooperation. It also works in their favor when they step out in the outer professional world [4; 7].

5. Integrative Approach. One of the vital characteristics of modern teaching methods is that it is integrative. Teachers link English curriculum topics, for instance, fashion, trends, culture, domestic violence, safety, pollution, food distribution, crime, medicine to other issues and make it integrative. By this, a learner can gain knowledge of more topics studying one [7].

6. Peer Cooperation Approach. Modern teaching methods not only encourage applicants for higher education by allowing them to present their ideas or initiative by eliciting their responses, studying their research, and allowing them to answer during interaction in English language practical classes, but also merge applicants for higher education based on interests, needs and feelings. Through instructional activities, university applicants for higher education learn to work cooperatively, and they appreciate their competitors' work as well. In the curriculum of the discipline "Foreign Language", learner's interests are considered most important, and they are guided towards their goals and careers [5; 7].

7. Collaborative Learning Approach. Earlier, when applicants for higher education were asked to revise the topic or syllabus during an examination or regular days, they used to revise the material on their own without any assistance or at home individually. This practice was widespread in traditional teaching methods. To deal with this issue or provide a more useful platform for applicants for higher education, university English language practical classes are coming up with collaborative learning. In this modern teaching method, teachers form a group of applicants for higher education where they can solve their problem, debate on topics and clear their queries. This helps learners in developing social skills and allows applicants for higher education to understand the English topic faster. In this modern teaching method, every student is a part of the success of a group as they help each other to reach the desired result, and they also learn to communicate with each other. Learners are also studying how to tolerate others, developing listening skills and team working capabilities. They will be able to meet different personalities and can get a genuine review of their work.

Applicants for higher education present their ideas and expect a response when they are learning in groups. It allows them to exchange their creativity and gain more knowledge. In return, it helps them to learn to face healthy criticism and cross-questions [7; 8].

In the frame of our research, we are moving to provide the real-life application of described modern teaching methods during English language practical classes with the help of created activities. So, we are going to take a 
detailed look on some of them, that can be useful for shaping soft skills in modern applicants for higher education of international relations specialty.

Think outside the box activity \#1. Gapped texts. AIM: to make applicants for higher education aware of what kind of words fill the gaps in this task type. PROCEDURE: 1 . Give out a copy of the jumbled text, in which paragraphs are not in order. Applicants for higher education read the paragraphs and put them in the correct order. When they are ready, they compare their answers in pairs or small groups. Check the answers with the whole class (see key below). 2. Hand out a copy of the original text. Tell applicants for higher education to find all collocations or typical phrases in the text and underline them. Again, applicants for higher education compare their answers in pairs / small groups. 3. Divide applicants for higher education into groups. Each group chooses 5 of the collocations listed and decides which word in the phrase will become a gap. These words are tipped out by applicants for higher education. 4. Tell applicants for higher education to turn their copies of original text and text with highlighted phrases face down. 5. Groups exchange their tipped-out text versions and try to fill in the missing words. Once finished, they compare their answers with the original text [8].

Think outside the box activity \#2. Gapped texts. AIM: to explore and understand the meaning of the grammatical structures used in a text. PROCEDURE: 1 . Give out a copy of the text to applicants for higher education. Applicants for higher education find and underline all the mistakes in different tenses in the text and check their answers in pairs or small groups. 2. In their pairs / groups, applicants for higher education find reasons why a particular tense is used in the text. To check their answers, you can either elicit and correct the answers with the whole class (if necessary), or provide answers yourself (table 1) [9].

\section{Gapped Text}

Table 1

\begin{tabular}{|l|l|}
\hline Original Text & Text With Grammatical Mistakes \\
\hline A SCHOOL FOR THE STARS The Brit & A SCHOOL FOR THE STARS The Brit \\
School opened in 1991. Over the years, it & School has opened in 1991. Over the years, \\
has produced many successful graduates. & it has producing many successful \\
Leona Lewis, Adele and Jesse J are three & graduates. Leona Lewis, Adele and Jesse J \\
former applicants for higher education - & are three former applicants for higher \\
they have sold millions of albums between & education - they sold millions of albums \\
them. In 2006, Leona Lewis won The X- & between them. In 2006, Leona Lewis won \\
Factor and she has already sold more than & The X-Factor and she has already selling \\
ten million albums worldwide. Adele has & more than ten million albums worldwide. \\
had No 1 hits in the British and American & Adele had No 1 hits in the British and \\
charts including the title track to the & American charts including the title track to \\
James Bond movie Skyfall. Singer and & the James Bond movie Skyfall. Singer and \\
songwriter Jesse J has already won & songwriter Jesse J already winning \\
numerous music awards and she's written & numerous music awards and she wrote \\
songs for other international artists such & songs for other international artists such \\
as Miley Cyrus. Another term has just & as Miley Cyrus. Another term has just \\
ended at the Brit School. Have they & ending at the Brit School. Did they \\
produced new stars? Probably! We haven't & produced new stars? Probably! We didn't \\
heard of them yet, but we will! & heard of them yet, but we will. \\
\hline
\end{tabular}


Think outside the box activity \#2. Pairs of sentences. AIM: to help applicants for higher education learn different collocations with the same word. PROCEDURE: 1. Hand out activity worksheet. Applicants for higher education put the words into the table to form collocations in which (left column) the key word "school" starts the phrase or (right column) the key word "school" is at the end of the phrase.

2. Applicants for higher education check the answers in a copy of the dictionary entries, or the teacher checks with the whole class. Each student translates example sentences from their entry into English. The translations are passed on round the group, and the sentences are translated back into English without the help of the dictionary entry [5].

Think outside the box activity \#3. Minidialogues. AIM: to become more aware of, learn and practice characteristic social exchanges (which make up part of the mini-dialogues task type) PROCEDURE: 1. In pairs, applicants for higher education get 5 cards with prompts and replies which together may form social mini-dialogues. For each prompt, there are 3 replies, two of which are correct, one incorrect OR inappropriate. 2. Applicants for higher education decide which replies are correct and appropriate. 3. They then act out their mini-dialogue in front of the class without using any prompts. The rest of the class have to guess what situation is being presented and what the dialogue sounds like [6].

Think outside the box activity \#4. Sentence transformations. AIM: to learn different ways of expressing the same meaning. PROCEDURE: This is a mixand-mingle activity 1. Applicants for higher education get cards with sentences - one sentence per student. In the whole set there are pairs of sentences which express the same meaning in 2 different ways. 2. Applicants for higher education are given 20 seconds / 30 seconds / one minute to remember their sentence. They then put their cards face down on their desks. 3. Students' task is to find a partner whose sentence expresses the same meaning in a different way. 4.Once applicants for higher education have found their partner, they teach each other their sentences. 5. Applicants for higher education sit down at their desks, uncover their cards and write down the paraphrase they have learnt from their partner. 6. To check, they pass their paraphrased sentence to their partner. 7 . This activity can be repeated 2-3 times so that applicants for higher education work with different sentences [4].

Think outside the box activity \#5. Word Building. Complete the sentences with the correct form of the words in capitals. 1. After the power cut, we couldn't get our TV set to work, so we called an to see what had happened. ELECTRIC. 2.The more I learn about nature, the more I find it. MIRACLE. 3. It's better to ask for assistance if you don't know how to _the system because it's not a matter of pressing the 'On' button. ACTIVE. 4. Don't you think that leaving young children in a car on a hot day is rather and that such parents should be somehow punished? RESPONSIBLE [3].

Think outside the box activity \#6. Transformations. 1 Our parents always took us for a walk along the pier during our summer holidays. WOULD Our parents _for a walk along the pier during our summer holidays. 2. The police say that the robbers probably stole the painting by mistake as they thought it was very valuable. MAY According to the police, the painting __mistake, in the belief that it was very valuable. 3 . As you get older, your eyesight deteriorates. WORSE The your eyesight becomes. 4.Mary, can you come and smell these prawns? I don't think they're edible any more. GONE Mary, can you come and smell these prawns? I think __ [4]. 
Think outside the box activity \#7. Sentence formation. 1. The manager _ (ought / not / criticise) Lesley in front of the others. But he rarely behaves appropriately. 2. Weren't you aware that taking _ (job / mean / move) the States? 3. The streets look really dirty. I wish _ (people / not / throw / litter) wherever they feel like it. 4. I _ (not / walk) that pavement if I were you - some paving slabs are missing and you might trip and hurt yourself [3].

\section{Conclusions}

\section{and}

research perspectives. All in all, the selfeducation of applicants for higher education and effective organization of their independent cognitive activity are issues of particular importance. Selfeducation is an important component of the English language practical classes and allows learners to produce needs for cognition, creative search, formation of curiosity, ability to study; independently organize cognitive-search and educational-research work. Thanks to self-education, applicants for higher education are not limited to the accumulation process of a significant amount of foreign language knowledge and are able to acquire independent skills of mastering them, elements of scientific research and scientific thinking, methods of scientific research in various English topics, form readiness to the constant renewal and acquisition of new foreign language knowledge, as well as to self-education and selfimprovement. The essence of the selfeducation is also conscious selforganization of the learning process, the formation of the necessary skills and abilities. Simultaneously, it promotes the development and improvement of qualities, abilities and skills of learners to study and adapt them for future professional activity by methods of selfeducation, self-learning and selfdevelopment.

During the research we have concluded that modern teaching methods have many advantages as compared with the traditional teaching methods [7].

- Unlike traditional teaching methods, modern teaching methods are more interactive and keep applicants for higher education intact.

- It maintains the interest of applicants for higher education by means of active mental participation individually and in groups.

- It helps to memorize the English concepts faster and for a more extended period than, for example, classical "Reading Comprehension" task.

- Modern teaching methods are less time-consuming. Teachers take less time to cover the syllabus, because writing on the blackboard is not required.

- Blackboard explanation of foreign language content is less explanatory than the real-life foreign language situations used in the modern teaching methods $[7 ; 11]$.

In short, the inclusion of modern teaching methods in the process of teaching the discipline "Foreign Language" is necessary as it opposes the idea of traditional forms of repetition and memorization of the syllabus to educate applicants for higher education. To develop decision-making skills, problemsolving skills, and critical thinking ability, modern teaching methods are best suited. The new ways of teaching during English language practical classes make applicants for higher education more productive and encourage them to collaborate. The educational process at universities is significantly different from other educational institutions due to the fact that there is an emphasis of applicants for higher education on mastering skills and methods by means of provision of individual educational and research work during English language practical classes, the transition of education to self-education as well as independent organization of behavior and the presence of value relations and orientations. 


\section{REFERENCES}

1. Chan, T.W., Roschelle, J., Hsi, S., Kinshuk, Sharples, M., Brown, T., \& Soloway, E. (2006). One-to-one technology-enhanced learning: An opportunity for global research collaboration. Research and Practice in Technology Enhanced Learning, 1(1), 3-29 [in English].

2. Collins, A., \& Halverson, R. (2009). Rethinking education in the age of technology: the digital revolution and schooling in America. New York: Teachers College Press, 3-12 [in English].

3. Council recommendation of 22 May 2018 on key competences for lifelong learning. (2018). 1-13 [in English].

4. Hendriks, D. (2016). Comparing traditional and digital learning methods to improve the learning outcomes of young children. Tilburg University, 5-18 [in English].

5. Digital Education at School in Europe. Eurydice Report. (2019). Luxembourg: Publications Office of the European Union, 9-45 [in English].

6. Education and Training. Retrieved from

https://ec.europa.eu/education/node_e $\mathrm{n}$ [in English].

7. Modern Teaching Methods - It's Time for the Change. Retrieved from https://eduvoice.in/modern-teachingmethods [in English].

8. Online education vs Traditional Education: Which one is better for you? Retrieved from https://www.classgap.com/en/blog/onli ne-education-traditional-educationwhich-one-better-for [in English].

Received: September 03, 2021 Accepted: October 06, 2021 